\title{
BIOCHEMICAL CONTROVERSIES REGARDING THE USE OF VEGETAL PROTEINS IN PERFORMANCE ATHLETES
}

\author{
Mădălina-Georgiana BĂTRÎNU ${ }^{1}$, Amelia TERO-VESCAN ${ }^{1 *}$, Amalia MIKLOS ${ }^{1}$ \\ ${ }^{1}$ Department of Fundamental Pharmaceutical Sciences, Discipline of Biochemistry, George Emil Palade \\ University of Medicine, Pharmacy, Science, and Technology of Târgu Mureș
}

*Correspondence:

Amelia TERO-VESCAN

amelia.tero-vescan@umfst.ro

Received: 12 June 2020; Accepted: 06 August 2020; Published: 30 December 2020

\begin{abstract}
Consumption of animal proteins is increasingly contested by those who choose a vegetarian diet, but for athletes, protein quality is a key component in optimizing athletic performance. The purpose of this article is to provide a nutritional guide for the vegetarian athlete who does not have to give up nutritional preferences to achieve performance in sports, and well-informed counseling by respecting principles of biochemistry can overcome the already known deficiencies of vegetal proteins in certain amino acids. The second aim of this paper is to recommend methods to assess protein quality by consulting the recommendations of the world's most important regulatory agency in the field of nutrition and food quality: the World Health Organization (WHO) and the Food and Agriculture Organization (FAO). In conclusion, even though vegetal proteins have a lower anabolic effect due to their low digestibility and a limited quantity of essential amino acids (especially leucine) and that amino acids of vegetal origin are more likely directed towards oxidative metabolism than towards anabolic processes, recent studies present strategies (consuming higher amounts of vegetal proteins, dietary supplements with amino acids) through which a well-planned vegetarian diet can have similar benefits to omnivorous diet regarding stimulating endogenous protein synthesis.
\end{abstract}

Keywords: leucine, protein synthesis, vegetal proteins, animal proteins.

\section{Introduction}

It is considered that in the Ancient Rome, gladiators were vegetarians, being called "hordearii (barley-eaters) - (Longo et al., 2008) and the first questions regarding the impact of diet on athletic performance have been asked since the 1980s (Nieman, 1988) when several literature studies reported enhanced muscular endurance in vegetarians over non-vegetarians, but these results have not been fully confirmed in subsequent studies.
An optimal diet with a balanced ratio between components (45-55\% carbohydrates, $20 \%$ proteins, and $25-30 \%$ lipids) must ensure the energy substrates and nutritional principles adapted to the age and the intensity of physical activity. For example, it was demonstrated that both carbohydrates and BCAAs (branched chain amino acids) influence phosphorylation of mTOR (mammalian target of rapamycin), indicating that the ratio between nutrients can 
have a huge impact on cellular processes (Solon-Biet et al., 2014).

It is well documented that diet and the quality of food components play a key role in the performance and health of athletes (Phillips and Van Loon, 2011). Regarding athletic performance, in terms of energy metabolism of striated muscle, the main energy substrates are carbohydrates and lipids (Bjorntorp, 1991). In order to favor the increase of muscle mass, a hypercaloric, high protein, normal or moderately low glycemic and normal lipidic diet is necessary. Proteins are macromolecules indispensable to the human body which, in addition to their structural role, also have a functional, physico-chemical and energetic role (Bytomski, 2018). Intense physical effort favors muscle hypertrophy correlated with the protein intake and a well-balanced amino acid composition (Phillips and Van Loon, 2011).

In the case of proteins, in addition to the quantitative requirement, there is the issue of their quality, the amino acid content being one of the most important criteria to define the quality of proteins (Wolfe et al., 2016). Of the total amino acids, 8 are considered essential for the body: leucine, isoleucine, methionine, valine, threonine, tryptophan, phenylalanine, and lysine. Proteins that contain all the essential amino acids in the required ratio are classified as proteins of high biological quality or complete proteins (Hoffman and Falvo, 2004). Performance athletes can choose between animal proteins such as milk casein, eggs, meat, fish, vegetal proteins such as soy, rice, peanuts, or a combination of them.

Recent studies confirm that plant proteins are inferior to animal proteins both quantitatively and qualitatively, and as they have an important role in the diet of athletes, serving as a substrate for sports performance, it is a subject that must be carefully regarded (Rogerson, 2017). Therefore, athletes with a vegetarian diet clearly consume a lower amount of protein than the omnivorous athletes (Berrazaga et al., 2019) and consequently, there is a lower anabolic effect of plant proteins also involving their incomplete content of essential amino acids.

There is also conclusive evidence that a vegetarian diet is associated with a multitude of health benefits for athletes (Appleby and Key, 2012; Marsh et al., 2012). Foods of vegetal origin are rich in antioxidants (polyphenols), micronutrients (vitamin $\mathrm{C}$ and $\mathrm{E}$ ) and carbohydrates that can enhance sports performance, but have the disadvantage of a poor content of certain nutrients such as vitamin $\mathrm{B} 12$, vitamin $\mathrm{D}$, omega-3 fatty acid docosahexaenoic acid, zinc, and iodine (Appleby and Key, 2012; Marsh et al., 2012; Clarys et al., 2014). On the other hand, the consumption of a high animal protein diet was associated with an increased risk of chronic metabolic diseases, especially cardiovascular diseases (Barnard et al., 2019).

Considering that vegetarian diets are more and more popular among athletes, because of ethical, religious, or ecological reasons, as well as for health purposes (Lynch et al., 2018), on the controversy regarding the quality of vegetal proteins but, also, that a well-planned vegetarian diet can fulfill nutritional needs of athletes, the purpose of this article is to assess the impact of the protein type (vegetable or animal) on sports performance. With this main purpose a review of the scientific literature using keywords: "vegetarian" AND "performance athletes" AND "proteins" on PubMed database was performed selecting 34 relevant articles for human nutrition.

2. Vegetal proteins vs. animal proteins for athletic performance

In order to improve athletic performance and ensure metabolic homeostasis, it is important to maintain the integrity of muscle mass. A net protein balance can be calculated 
as a ratio between the amount of catabolized and the amount of synthesized proteins and this ratio depends a lot on physical activity, dietary intake of proteins and amino acids as well as on their quality and quantity. A high protein intake determined short time effects (post-prandial increase of protein synthesis) and longtime effects (increased muscle mass) (Berrazaga et al., 2019).

It is considered that both in strength sports (weightlifting, weight throwing, etc.) (TinlineGoodfellow et al., 2020) and in endurance sports (marathon, cycling) (Kato et al., 2016; McKendry et al., 2019) protein intake should be higher than in a normal, healthy adult with moderate physical activity.

Most authors consider the optimal protein intake for adults to be $0.8 \mathrm{~g} / \mathrm{kg}$ body weight (Campbell et al., 2007). Normally, in the case of a healthy adult, there must be a balanced nitrogen balance, the protein nitrogen ingested must be found entirely in the nitrogen eliminated in the form of urea. Athletes need higher protein content in the diet, the correct nitrogen balance ranges from 1.2 to $2.0 \mathrm{~g} / \mathrm{kg}$ b.w. because the need of amino acids for endogenous protein synthesis is higher (Joy et al., 2013; Phillips and Van Loon, 2011).

Optimizing the protein intake for athletes to increase sports performance is a subject of continuous debate and requires a special evaluation of both the quantity and the quality of proteins (Berrazaga et al., 2019).

There are several methods to determine the quality of proteins. In 1989, the Joint Food and Agriculture Organization of the United Nations/World Health Organization (FAO/WHO) Expert Consultation on Protein Quality Evaluation recommended a series of parameters to evaluate the quality of proteins by assessing the nitrogen balance and considering to the degree of digestibility, net protein utilization and their biological importance (FAO/WHO, 2013).

\subsection{Assessing the quality of proteins by protein digestibility-corrected amino acid score/digestible indispensable amino acid score}

The Regarding digestibility, it is known that vegetal proteins are less digestible than animal proteins (FAO/WHO, 2013). This may be due to structural differences between the two types of proteins. The secondary structure of plant proteins consists of high beta chain content and a relatively low percentage of alpha-helix. It is assumed that in the gastrointestinal tract there is a resistance to proteolysis of vegetal proteins due to the high percentage of beta-sheet conformation, thus explaining the low digestibility of plant proteins (Carbonaro et al., 2012). Moreover, vegetal proteins contain non-starch polysaccharides or fibers that prevent the access of enzymes to the protein, thus leading to a decrease in digestibility (Duodua et al., 2003). The presence in plants of active compounds such as phytic acid or protease inhibitors can also influence the digestibility of proteins (Duodua et al., 2003). Vegetal proteins from processed foods present a higher digestibility rate (with 18\%) compared to unprocessed foods (Wright et al., 2017).

The best parameter to characterize the quality of proteins in terms of digestibility is PDCAAS (Protein Digestibility-Corrected Amino Acid Score) and DIAAS (Digestible Indispensable Amino Acid Score), more recently introduced into practice. For a protein to contain all the essential amino acids PDCAAS should be no less than 1. As the use of PDCAAS has been increasingly criticized due to numerous limitations (Leser, 2013), DIAAS was introduced for quality assessment of proteins. Both scores prove the superiority of animal proteins over vegetal ones in terms of protein digestibility (Lynch et al., 2018; Leser, 2013). 
However, these two parameters do not really show the anabolic potential of each type of protein, but rather a method to determine the minimum amino acids needed to prevent protein deficiency in the whole body. For example, the PDCAAS score for soybeans (0.91) is similar to that of beef protein (0.92). So theoretically both types of protein should stimulate approximately similar protein synthesis. However, a recent study by Philips et al. (2012) demonstrates the superior postprandial anabolic effect of beef proteins compared to soybean. Further on, other studies compared soy protein isolates with milk proteins, as both have similar PDCAAS, but as presented in the previous study these two types of proteins have different anabolic abilities both during rest and post-exercise (Tang et al., 2009). Based on these data, it was recommended that vegetarian athletes should consume a higher amount of protein due to the poor digestibility of plant proteins (Kniskern and Johnston, 2011).

Literature data are controversial, a pilot study conducted over 8 weeks, of HighIntensity Functional Training, shows that both animal proteins (whey proteins) and vegetal (pea proteins) have similar effects upon body composition and muscle strength (Banaszek et al., 2019). Joy et al. (2013) and Mobay et al. (2017), in similar studies, using rice and whey proteins and whey protein and soy proteins, respectively, obtained no statistically significant difference between the groups (Joy et al., 2013; Mobley et al., 2017). Another clinical study conducted in 2015 on a larger number of participants compared to previous studies $(n=161)$ shows that the administration of vegetal protein supplements (peas) used in combination with resistance training could be just as effective as whey protein supplements in terms of increasing strength and muscle mass (Babault et al., 2015) while a recent review by Craddock et al. (2016) concludes that a vegetarian diet does not improve athletic performance but does not negatively influence it either (Craddock et al., 2016).

\subsection{Assessing the quality of proteins by BCAAs content}

For elite sports performance, a high-quality protein must contain all the essential amino acids and especially a proper amount of BCAAs. Most plant proteins do not contain all the essential amino acids or in the right amount, resulting in a decrease in their biological value.

BCAAs, leucine, valine and isoleucine, represent more than a third of muscle protein amino acids (Joy et al., 2013). It commonly accepted that essential amino acids and especially BCAAs induce an anabolic effect by stimulating protein synthesis, and their deficiency can limit the synthesis process (Wolfe, 2017; Joy et al., 2013). A study by Garlick et al state that BCAAs have the ability to stimulate protein synthesis in the same way as the other 8 essential amino acids (Garlick, 2005). High-doses of leucine can independently stimulate protein synthesis and inhibit degradation, this effect is potentiated by a small increase in insulinemia (Garlick, 2005; Wolfe, 2017). However, some studies recommend the use of leucine in the presence of other essential amino acids rather than alone (Wolfe, 2017), therefore it can be concluded that the optimal composition of proteins depends a lot on leucine and vice versa. Recent studies have shown that supplementation with 2-3 $\mathrm{g}$ of leucine or $0.05 \mathrm{~g} / \mathrm{kg}$ b.w. increased protein synthesis (Norton and Wilson, 2009; Tipton et al., 1999). Above this threshold, there are no benefits in terms of maximizing protein synthesis. For example, consuming $40 \mathrm{~g}$ of egg protein (4 g leucine) did not show a higher increase in muscle protein synthesis than ingesting $20 \mathrm{~g}$ egg protein ( $2 \mathrm{~g}$ leucine) (Tang et al., 2009). 
Plant-based proteins contain about 6-8\% leucine, a reduced quantity compared to animal- proteins that contain about $8-11 \%$ leucine. There are also vegetal foods with a high content of BCAAs such as seeds, tree nuts and chickpeas, so the need for BCAAs could be met by consuming a variety of enriched proteins from plant foods (Rogerson, 2017). It was demonstrated that adding leucine to a plant-based diet (Norton et al., 2012) or consuming a larger amount of vegetal proteins increasing the percentage of leucine above the threshold level (Joy et al., 2013), the rate of protein synthesis is similar to a diet based on animal products. This hypothesis could support the increasing number of vegetarians among performance athletes.

A study by Yang et al. in 2012 reported a high rate of leucine oxidation after ingestion of $40 \mathrm{~g}$ of soy protein, compared to the same amount of whey protein. So, it can be concluded that plant proteins are directed more towards oxidation processes than towards protein synthesis (Yang et al., 2012; van Vliet et al., 2015).

\subsection{Other nutrients of vegetal origin and athletic performance}

Although animal proteins are considered to have a better quality than those of vegetal origin, nowadays other aspects are also considered as vegetal food products (from quinoa, hemp seeds, etc.) also contain other nutrients responsible for improving sports performance among athletes.

A diet based on vegetal products decreases important parameters of lipid metabolism (hypercholesterolemia, hypertriglyceridemia, etc.), decreasing, therefore, the metabolic risk (Barnard et al., 2019) and, in the same time, increasing the maximum aerobic effort capacity by increasing $\mathrm{VO}_{2}$ max (maximum rate of oxygen consumption) (Smith et al., 2015).
As vegetal products contain a high amount of carbohydrates, the major energy substrate during aerobic exercise, a vegetarian diet can increase sports endurance, both during sport events or on long term (Jacobs and Sherman, 1999).

Intense physical effort can generate free radicals that can then cause muscle weakness (Viña et al., 2000). In case of vegetarian athletes, a high antioxidant activity was observed due to the high amounts of vitamin C, $\mathrm{E}$ and beta-carotene in plants (Rauma et al., 1995), such as beets, garlic, onions, cherry juice (Barnard et al., 2019). Vegetarian diet also presents an anti-inflammatory effect. A 2017 meta-analysis, based on 18 previous studies, on vegetarian subjects, over two years, showed decreases in plasma C-reactive protein, as a marker of inflammation, thus suggesting that plant foods can reduce post-exercise inflammation and facilitate recovery (Haghighatdoost et al., 2017).

\section{Conclusions}

1. Literature data available so far emphasize that the "classic" nutritional principles don't recommend a vegetarian diet for performance athletes as plant proteins have a lower quality than animal proteins, both in terms of content in essential amino acids and digestibility.

2. Recent studies show that vegetarian performance athletes only need larger amounts of vegetal proteins to provide the essential amino acids, especially leucine which is the biomarker of a protein's involvement in endogenic anabolic processes.

3. Despite limited number of studies and study participants, literature data recommend a well-planned vegetarian diet, referring to certain nutritional strategies, in order to improve the quality of proteins (fortification of vegetal proteins with amino acids, consumption 
of higher amounts of vegetal proteins) and, in the same time, highlight the presence of other compounds, specific for vegetal foods, beneficial in terms of sports performance. Still, this subject remains a controversial one.

4. This paper presents biochemical aspects of protein metabolism and tries to balance, as well as possible, the "pros" and "cons" of adopting a vegetarian diet in performance athletes, in whom the protein turn-over is high and protein malnutrition or deficiency in certain amino acids, especially leucine may represent an intrinsic risk factor for the athlete's health, along with other well-known factors: increased cardiovascular risk, hyperhomocysteinemia, low intake of omega 3 fatty acids, etc. The possibility of synergism between these risk factors remains a topic that can be further researched.

\section{Conflict of Interest}

The authors declare that the research was conducted in the absence of any commercial or financial relationships that could be construed as a potential conflict of interest.

\section{References}

1. $* * *$ (2013) FAO. Dietary Protein Evaluation in Human Nutrition: Report of an FAO Expert Consultation 2011; FAO Food and Nutrition Paper 92. http://www.fao.org/ag/humannutrition/3597 8-02317b979a686a57aa4593304ffc17f06. pdf (accessed on June the $11^{\text {th }}$ )

2. Appleby PN, Key TJ (2016) The long-term health of vegetarians and vegans. Proc Nutr Soc 75(3):287-293. https://doi.org/10.1017/S002966511500433 4

3. Babault N, Païzis C, Deley G, GuérinDeremaux L, Saniez MH, Lefranc-Millot C, Allaert FA (2015) Pea proteins oral supplementation promotes muscle thickness gains during resistance training: a doubleblind, randomized, Placebo-controlled clinical trial vs. Whey protein. J Int Soc Sports Nutr 12(1):3. https://doi.org/10.1186/s12970-014-0064-5

4. Banaszek A, Townsend JR, Bender D, Vantrease WC, Marshall AC, Johnson KD (2019) The Effects of Whey vs. Pea Protein on Physical Adaptations Following 8Weeks of High-Intensity Functional Training (HIFT): A Pilot Study. Sports (Basel) 7(1):12.

https://doi.org/10.3390/sports7010012

5. Barnard ND, Goldman DM, Loomis JF, Kahleova H, Levin SM, Neabore S, Batts TC (2019) Plant-Based Diets for Cardiovascular Safety and Performance in Endurance Sports. Nutrients 11(1):130. DOI: $10.3390 /$ nu11010130

6. Berrazaga I, Micard V, Gueugneau M, Walrand S (2019) The Role of the Anabolic Properties of Plant- versus Animal-Based Protein Sources in Supporting Muscle Mass Maintenance: A Critical Review. Nutrients 11(8):1825. DOI: 10.3390/nu11081825

7. Bjorntorp $P$ (1991) Importance of fat as a support nutrient for energy: Metabolism of athletes. J Sports Sci 9(1): 71-76. https://doi.org/10.1080/0264041910872986 7

8. Bytomski JR (2018) Fueling for Performance, Sports Health 10(1):47-53. DOI: $10.1177 / 1941738117743913$

9. Campbell B, Kreider RB, Ziegenfuss $T$ (2007) International Society of Sports Nutrition position stand: protein and exercise, J Int Soc Sports Nutr 4:8. https://doi.org/10.1186/1550-2783-4-8

10. Carbonaro M, Maselli P, Nucara A (2012) Relationship between digestibility and secondary structure of raw and thermally treated legume proteins: a Fourier transform infrared (FT-IR) spectroscopic 
study. Amino Acids 43(2):911-921. DOI: 10.1007/s00726-011-1151-4

11. Clarys P, Deliens T, Huybrechts I, Deriemaeker P, Vanaelst B, De Keyzer W, Hebbelinck M, Mullie P (2014) Comparison of nutritional quality of the vegan, vegetarian, semi-vegetarian, pescovegetarian and omnivorous diet. Nutrients 6(3):1318-1332. DOI: 10.3390/nu6031318

12. Craddock JC, Probst YC, Peoples GE (2016) Vegetarian and Omnivorous Nutrition - Comparing Physical

Performance. Int J Sport Nutr Exerc Meta 26(3):212-220. DOI: 10.1123/ijsnem.20150231

13. Duodu KG, Taylor JRN, Belton PS, Hamaker BR (2003) Factors affecting sorghum protein digestibility, J Cereal Sci 38:117-131. https://doi.org/10.1016/S07335210(03)00016-X

14. Garlick PJ (2005) The role of leucine in the regulation of protein metabolism. J Nutr 135(6):1553S-6S. https://doi.org/10.1093/jn/135.6.1553S

15. Haghighatdoost F, Bellissimo N, Totosy de Zepetnek JO, Rouhani MH (2017) Association of vegetarian diet with inflammatory biomarkers: a systematic review and meta-analysis of observational studies. Public Health Nutr 20(15):2713-2721.

DOI: $10.1017 / \mathrm{S} 1368980017001768$

16. Hoffman JR, Falvo MJ (2004) Protein Which is Best?. J Sports Sci Med 3(3):118-130. PMCID: PMC3905294.

17. Jacobs KA, Sherman WM (1999) The efficacy of carbohydrate supplementation and chronic high- carbohydrate diets for improving endurance performance. Int $\mathrm{J}$ Sport Nutr 9(1):92-115. DOI: 10.1123/ijsn.9.1.92

18. Joy JM, Lowery RP, Wilson JM, Purpura M, De Souza EO, Mc Wilson S, Kalman DS, Dudeck JE, Jäger R (2013) The effects of 8 weeks of whey or rice protein supplementation on body composition and exercise performance. Nutr J 12:86. https://doi.org/10.1186/1475-2891-12-86

19. Kato H, Suzuki K, Bannai M, Moore DR (2016) Protein Requirements Are Elevated in Endurance Athletes after Exercise as Determined by the Indicator Amino Acid Oxidation Method. PLoS One 11(6):e0157406.

DOI: 10.1371/journal.pone.0157406

20. Kniskern MA, Johnston CS (2011) Protein dietary reference intakes may be inadequate for vegetarians if low amounts of animal protein are consumed. Nutrition 27(6):727-730.

DOI: 10.1016/j.nut.2010.08.024

21. Lemon PW, Yarasheski KE, Dolny DG (1984) The importance of protein for athletes. Sports Med 1(6) 474-484. DOI: 10.2165/00007256-198401060-00006

22. Leser S (2013) The 2013 FAO report on dietary protein quality evaluation in human nutrition: Recommendations and implications, Nutr Bull 38 (4): 421-428. https://doi.org/10.1111/nbu.12063

23. Longo UG, Spiezia F, Maffulli N, Denaro V (2008) The Best Athletes in Ancient Rome were Vegetarian!. J Sports Sci Med 7(4):565. PMID: 24137094; PMCID: PMC3761927.

24. Lynch H, Johnston C, Wharton C (2018) Plant-Based Diets: Considerations for Environmental Impact, Protein Quality, and Exercise Performance. Nutrients 10(12):1841. DOI: 10.3390/nu10121841

25. Marsh K, Zeuschner C, Saunders A (2012) Health Implications of a Vegetarian Diet: A Review, Am J Lifestyle Med 6(3):250-267. https://doi.org/10.1177/1559827611425762

26. McKendry J, Shad B, Smeuninx B, Oikawa SY, Wallis G, Greig C, Phillips S, Breen L (2019) Comparable Rates of Integrated Myofibrillar Protein Synthesis Between 
Endurance-Trained Master Athletes and Untrained Older Individuals, Front Physiol 10:1084.

https://doi.org/10.3389/fphys.2019.01084

27. Mobley CB, Haun CT, Roberson PA, Mumford PW, Romero MA, Kephart WC, Anderson RG, Vann CG, Osburn SC, Pledge CD, Martin JS, Young KC, Goodlett MD, Pascoe DD, Lockwood CM, Roberts MD (2017) Effects of Whey, Soy or Leucine Supplementation with 12 Weeks of Resistance Training on Strength, Body Composition, and Skeletal Muscle and Adipose Tissue Histological Attributes in College-Aged Males. Nutrients 9(9):972. doi: 10.3390/nu9090972.

28. Nieman DC (1988) Vegetarian dietary practices and endurance performance. Am J Clin Nutr 48(3):754-761.

doi: 10.1093/ajcn/48.3.754.

29. Norton L, Wilson GJ (2009) Optimal protein intake to maximize muscle protein synthesis. Agro Food industry hi-tech 20:54-57

30. Norton LE, Wilson GJ, Layman DK, Moulton CJ, Garlick PJ (2012) Leucine content of dietary proteins is a determinant of postprandial skeletal muscle protein synthesis in adult rats. Nutr Metab (Lond) 9(1):67. https://doi.org/10.1186/1743-70759-67

31. Phillips SM, Van Loon LJC (2011) Dietary protein for athletes: From requirements to optimum adaptation, J Sports Sci 29(1):S29-S38.

DOI: 10.1080/02640414.2011.619204

32. Phillips SM (2012) Nutrient-rich meat proteins in offsetting age-related muscle loss. Meat Sci 92(3):174-178. DOI: 10.1016/j.meatsci.2012.04.027

33. Rauma AL, Törrönen R, Hänninen $\mathrm{O}$, Verhagen H, Mykkänen H (1995) Antioxidant status in long-term adherents to a strict uncooked vegan diet. The American
Journal of Clinical Nutrition 62(6):12211227. DOI: 10.1093/ajcn/62.6.1221

34. Rogerson D (2017) Vegan diets: practical advice for athletes and exercisers. J Int Soc Sports Nutr 14:36.

https://doi.org/10.1186/s12970-017-0192-9

35. Smith MM, Lucas AR, Hamlin RL, Devor ST (2015) Associations among hemorheological factors and maximal oxygen consumption. Is there a role for blood viscosity in explaining athletic performance?. Clin Hemorheol Microcirc 60(4):347-362. DOI: 10.3233/CH-131708

36. Solon-Biet SM, McMahon AC, Ballard JWO, Ruohonen K, Wu LE, Cogger VC, Warren A, Huang X, Pichaud N, Melvin RG, Gokarn R, Khalil M, Turner N, Cooney GJ, Sinclair DA, Raubenheimer D, Le Couteur DG, Simpson SJ (2014) The Ratio of Macronutrients, Not Caloric Intake, Dictates Cardiometabolic Health, Aging, and Longevity in Ad Libitum-Fed Mice, Cell Metabolism 19(3): 418-430. doi: 10.1016/j.cmet.2014.02.009

37. Tang JE, Moore DR, Kujbida GW, Tarnopolsky MA, Phillips SM (2009) Ingestion of whey hydrolysate, casein, or soy protein isolate: effects on mixed muscle protein synthesis at rest and following resistance exercise in young men. $\mathbf{J}$ Appl Physiol 107(3):987-992.

DOI: 10.1152/japplphysiol.00076.2009

38. Tinline-Goodfellow C, West D, Malowany J, Gillen J, Moore D (2020) An Acute Reduction in Habitual Protein Intake Attenuates Post Exercise Anabolism and May Bias Oxidation-Derived Protein Requirements in Resistance Trained Men, Front Nutr, 7:55.

DOI: $10.3389 /$ fnut.2020.00055

39. Tipton KD, Ferrando AA, Phillips SM, Doyle D Jr, Wolfe RR (1999) Post-exercise net protein synthesis in human muscle from 
orally administered aminoacids, Am J Physiol 276:E628-E634.

DOI: 10.1152/ajpendo.1999.276.4.E628

40. van Vliet S, Burd NA, van Loon LJ (2015)

The Skeletal Muscle Anabolic Response to

Plant- versus Animal-Based Protein Consumption. J Nutr 145(9):1981-1991. DOI: 10.3945/jn.114.204305

41. Viña J, Gomez-Cabrera MC, Lloret A, Marquez R, Miñana JB, Pallardó FV, Sastre $\mathrm{J}$ (2000) Free radicals in exhaustive physical exercise: mechanism of production, and protection by antioxidants. IUBMB Life 50(4-5):271-277. DOI: 10.1080/713803729

42. Wolfe RR, Rutherfurd SM, Kim IY, Moughan PJ (2016) Protein quality as determined by the Digestible Indispensable Amino Acid Score: evaluation of factors underlying the calculation. Nutr Rev 74(9):584-599.

DOI: 10.1093/nutrit/nuw022

43. Wolfe RR (2017) Branched-chain amino acids and muscle protein synthesis in humans: myth or reality?. J Int Soc Sports Nutr 14:30. https://doi.org/10.1186/s12970017-0184-9

44. Wright CS, McMorrow AM, WeinheimerHaus EM, Campbell WW (2017) Whey Protein Supplementation and Higher Total Protein Intake Do Not Influence Bone Quantity in Overweight and Obese Adults Following a 36-Week Exercise and Diet Intervention. J Nutr 147(2):179-186. doi: 10.3945/jn.116.240473

45. Yang Y, Churchward-Venne TA, Burd NA, Breen L, Tarnopolsky MA, Phillips SM (2012) Myofibrillar protein synthesis following ingestion of soy protein isolate at rest and after resistance exercise in elderly men. Nutr Metab (Lond) 9(1):57. DOI: 10.1186/1743-7075-9-57 